\title{
MANAGEMENTUL RESURSELOR UMANE ÎN ORGANIZAȚIILE DIN ROMÂNIA ȘI SPECIFICUL ÎN SISTEMUL NAȚIONAL DE APĂRARE
}

\author{
HUMAN RESOURCES MANAGEMENT IN ROMANIAN ORGANIZATIONS \\ AND THE SPECIFICITY OF THE NATIONAL DEFENCE SYSTEM
}

Alina-Elena IONAȘCU (HULUBA)*

\begin{abstract}
Lucrarea este scrisă din perspectiva contextuală a înțelegerii și revizuirii proceselor asociate managementului resurselor umane (MRU) la nivelul organizațiilor. În consecință, scopul acestei lucrări este de a explora tendințele practicilor de MRU pentru a identifica acele caracteristici specifice organizațiilor din România și pentru a stabili specificul acestuia în sistemul național de apărare. La începutul lucrării, se vor face referiri la cadrul general al cercetării și se vor puncta reperele evolutive și conceptuale de importanță pentru acest demers. Caracteristicile managementului resurselor umane în organizațiile din România sunt stabilite prin comparații cu alte țări, axa centrală de comparații fiind reprezentată de statele membre ale Uniunii Europene (UE). Pornind de la rezultatele acestei analize, sunt examinate particularitățile MRU din domeniul apărării, identificate prin studiul cadrului normativ, și sunt făcute observaţii cu privire la orientările de actualitate. În secțiunea concluzii, sunt expuse principalele idei rezultate, contribuțiile personale, problemele deschise și limitele cercetării.
\end{abstract}

This paper is written from the contextual perspective of understanding and reviewing the processes associated with human resources management (HRM) in organizations. Consequently, the purpose of this paper is to explore the trends of HRM practices in order to identify the specific characteristics of Romanian organizations and to establish its specificity in the national defense system. In the first part of the paper we will refer to the research framework and point out the evolving and conceptual benchmarks that are of importance to this approach. The characteristics of human resources management in Romanian organizations are established by comparisons with other countries, while the central axis of comparison is represented by the member states of the European Union (EU). Starting from the results of this analysis, the particularities of HRM that are defense-related, identified through the study of the regulatory framework and comments regarding the current guidelines are made. In the conclusions, the paper will present main ideas resulted, personal contributions, issues addressed and research limitations.

Cuvinte-cheie: managementul resurselor umane; organizații; România; apărare; particularități; orientări.

Keywords: human resources management; organizations; Romania; defence; particularities; guidelines.

Într-o lume globalizată, bazată pe interacțiunea dintre state/organizații/indivizi, și într-o Uniune Europeană a cărei preocupare este integrarea membrilor diverși, înțelegerea dihotomiei și identificarea punctelor de convergență dintre managementul resurselor umane în organizațiile civile și cele militare constituie un aspect de interes pentru promovarea colaborării, evitarea conflictelor și menținerea păcii durabile. Spre exemplu, dacă o anumită organizație are o anume abordare privind gestionarea resurselor umane, foarte discrepantă,

\section{*Baza 91 Logistică a Forțelor Aeriene General „Andrei Popovici”, Otopeni e-mail: ionascu.alina.03@gmail.com}

comparativ cu tendinţele manifestate la nivel global/european, iar organizaţiile străine cu care acestea colaboreză își ghidează acțiunile în acord cu orientările consacrate, și nu cu cele pe care aceasta le practică, pot să apară deficiențe și situații dificile.

\section{Lacuna de cercetare}

Deși problematica particularităţilor managementului resurselor umane în organizațiile militare a fost pusă în articole publicate în țară şi se încadrează în preocupările mele de cercetare, nu le-am putut valorifica în cel mai înalt grad, deoarece analiza privind MRU din domeniul militar, în raport cu tendințele din mediul civil, consacrate la nivel internațional, lipsea din aceste demersuri 
științifice. Ținând cont de interesul propriu de cercetare privind problema transformării MRU din domeniul militar, încadrată la nivel național ca fiind una dintre principalele direcții de dezvoltare a capabilităților de apărare pentru următorii trei ani, datorită obiectivului său final - asigurarea unui personal de înaltă calitate în vederea satisfacerii nevoii strategice a sistemului de a face faţă noilor provocări ale mediului de securitate -, am ales să abordez această lacună. Acest lucru este legat de faptul că cercetătorii din domeniu recunosc necesitatea de a explora modul în care practicile MRU se manifestă în organizații din diferite țări pentru a înțelege observațiile legate de specificitatea MRU în organizații, astfel încât să poată fi extrapolate idei aplicabile în contexte relevante.

\section{Cadrul general al cercetării}

Un domeniu în plină expansiune în MRU este extinderea interesului de la analiza unor teorii și practici din punct de vedere universal la analiza lor contextuală. Considerând aceste aspecte, prezenta lucrareseîncadreazădinpunctuldevederealcadrului științific general în dezbaterea ,convergență versus divergență”. Aceasta se încadrează în cercetările de tip calitativ, articolul vizând o analiză tematică (oferă repere conceptuale, evolutive și subliniază actualitatea abordării tematice), comparativă și empirică prin observarea realității și prin studiul cadrului normativ specific. Pentru aceasta, în prima parte, lucrarea se concentrează pe analiza comparativă a tendințelor raportate de organizații din spațiul european și noneuropean, obiectivul fiind acela de a evidenția cum sunt organizațiile din România din punctul de vedere al practicilor specifice proceselor asociate MRU.

În lumina acestui context, în cea de a doua parte, se va descrie și explica specificul general al MRU în organizațiile militare din România, prin studiul bibliografic al lucrărilor de specialitate și al cadrului normativ în vigoare. Premisa acestei lucrări este, în consecință, aceea conform căreia o bună înțelegere cu privire la orientările de MRU aplicate în organizații din România, raportat la cele din spațiul european și noneuropean, poate fi utilă pentru a explora specificul MRU din organizațiile militare și pentru a trece în revistă câteva orientări de actualitate care să permită funcționarea acestuia la cel mai înalt nivel. Evident, consider că este greu de conceput un proiect de transformare a managementului resurselor umane din armata României care să nu aibă drept fundament înțelegerea specificului și dezvoltarea acestuia în acord cu tendințele, dar la nivelul permis de particularităţile specifice misiunii atribuite. În consecință, prin această abordare, articolul se dorește a fi un pas incipient spre realizarea unui studiu serios, vizavi de identificarea celor mai potrivite instrumente, acțiuni și procese necesare a fi adoptate pentru transformarea MRU din armata României, în conformitate cu obiectivele strategice stabilite.

Așadar, prin elaborarea acestei lucrări, vizez următoarele: să evidențiez practicile de MRU specifice organizațiilor din România, prin comparație cu organizațiile din spațiul UE, și să evidențiez specificul MRU în organizațiile militare, cu implicații pentru cercetări viitoare și aplicații (de exemplu, care sunt aspectele ce pot fi revizuite pentru transformarea MRU din sistemul național de apărare). Din punctul de vedere al rezultatelor așteptate, această lucrare își propune să surprindă tendințele de succes ale MRU la nivelul organizațiilor din alte țări, caracteristicile organizațiilor din România, specificul și posibilele orientări pentru sistemul național de apărare, prin referire la metode, instrumente, procese și acțiuni relevante domeniului.

\section{Repere evolutive și conceptuale privind MRU}

Importanța dezvoltării teoriei şi practicilor privind întrebuinţarea oamenilor în cadrul organizațiilor s-a conștientizat în mod treptat, pe măsura apariţiei unor fenomene cu impact global asupra activităților de pe piața muncii. Dezvoltarea industrială de la începutul secolului XX a propulsat atât creșterea interesului angajatorilor pentru activitățile legate de personal, cât și dezvoltarea primelor cercetări științifice privind munca omului. Atunci, viziunea tayloristă ${ }^{1}$ reflecta destul de bine raționalizarea organizării muncii în mediul industrial, apariția conceptului de funcțiune administrativă evidenția importanța acțiunilor de „a prevedea, a organiza, a comanda și a controla activitățile grupurilor de oameni"2 pentru succesul întreprinderilor, iardezvoltareamodeluluibirocratic de către Max Weber nu doar că făcea, pentru prima dată, o referire distinctă la funcțiunea de personal, ci accentua rolul activităților specifice de 
recrutare, selecție și promovare a angajaților. Criza economică ce a urmat Primului Război Mondial a condus la apariția unor noi responsabilități pe linia funcțiunii de personal, remarcându-se studiile care arătau importanța raporturilor dintre indivizi la locul de muncă asupra productivității ${ }^{3}$. Economia postindustrială de după cel de al Doilea Război Mondial a condus la conștientizarea statutului de resursă competitivă critică a personaluluiși, implicit, la popularizarea termenului de ,resurse umane" și la apariția unor funcții independente, specifice gestionării resurselor umane, cum ar fi selecția, instruirea, compensarea și evaluarea performanței ${ }^{5}$.

Drept urmare, în consonanță cu raționamentul privind importanța concentrării MRU asupra acelor abordări și practici care contribuie la obținerea rezultatelor dorite, în contextul actual drumul cercetătorilor și al practicienilor din domeniu continuă să se îndrepte spre identificarea acelor idei şi instrumente congruente cu obiectivele afacerii, care au capacitatea de a îmbunătăți performanța organizațională pe o piață asociată cu inovația, viteza și adaptabilitatea. În literatura de specialitate, există mai multe abordări relativ asemănătoare în ceea ce privește conceptul de management al resurselor umane. Pentru a surprinde actualitatea temei, această lucrare se raportează la abordarea cuprinzătoare a managementului resurselor umane, potrivit căreia acesta ,reprezintă procesul de realizare a obiectivelor organizaţionale prin atragerea, reţinerea, dezvoltarea, îndepărtarea şi utilizarea corectă a resurselor umane într-o organizaţie".

$\mathrm{Cu}$ alte cuvinte, în această lucrare voi avea în vedere analiza proceselor specifice de recrutare, selecție, formare și evaluare, din perspectiva practicilor utilizate (instrumente, procese, acțiuni) în organizații - considerate a fi ,,un grup de persoane care lucrează împreună" .

\section{Tendințe privind MRU și caracteristicile specifice organizațiilor din România}

În această secțiune, voi analiza, din perspectivă comparativă, tendințele internaționale și caracteristicile managementului resurselor umane practicat în organizațiile din România. Pentru a da o validitate acestei analize, am avut în vedere examinarea datelor ultimului studiu, publicat de Cranet, ținând cont și de literatura de specialitate din domeniu studiată.
Cranet este o rețea recunoscută la nivel mondial pentru reperele oferite cu privire la aspectele evolutive specifice managementului internaţional al resurselor umane, implementat de organizațiile angajatoare din Europa și din alte țări ale lumii. Coordonată de Cranfield School of Management din Marea Britanie, Cranet - o rețea bazată pe colaborarea a peste 40 de universități și școli de afaceri de pe șase continente -, a fost înființată în anul 1989 pentru a răspunde nevoii de informații privind practica și performanța MRU în Europa și de acum în întreaga lume ${ }^{8}$. Cercetarea Cranet se bazează pe datele colectate în perioada 20142015, care a fost detaliată în raportul publicat în anul 2017. Utilizând datele Cranet, vom identifica tendințele generale, $\mathrm{cu}$ accent pe datele furnizate în ansamblu de organizațiile din țările integrate în Uniunea Europeană, considerate a fi axa principală de analiză.

Presupunând că MRU din România are unele trăsături distincte, vom analiza abordarea organizațiilor din țara noastră în comparație cu tendinţele generale, raportate de către celelalte state participante la studiu, accentul căzând pe organizațiile încadrate în axa principală de analiză.

În raportul publicat în 2017, Cranet și-a concentrat cercetarea pe un total de 35 de țări, astfel: 21 din cele 27 țări membre ale Uniunii Europene (exceptie fac Polonia, Bulgaria, Irlanda, Portugalia, Cehia și Malta), 6 țări care nu fac parte din această comunitate (Islanda, Norvegia, Rusia, Serbia, Elveția și Turcia) și 8 țări noneuropene (Australia, Brazilia, China, Indonezia, Israel, Filipine, Africa de Sud și SUA). Instrumentul de anchetă utilizat a fost un chestionar, concentrat în șase secțiuni, și anume: activitatea de ansamblu a MRU în organizaţie, practicile de resurse umane, dezvoltarea angajaților, compensații și beneficii, relațiile cu angajații și comunicarea, detalii organizaționale - care s-a adresat managerilor de resurse umane ale organizațiilor cu cel puțin 100 de angajați.

$\mathrm{Cu}$ toate că țările participante au trimis un total de 59.156 de chestionare, după eliminarea datelor lipsă, a rezultat o rată de răspuns globală în valoare de 10,3\%. În comparație cu rata de răspuns de 21,27\%, înregistrată la nivelul UE, România a avut o rată substanțial mai mică, de $7,76 \%$. In ceea ce privește distribuția sectorială a eșantionului, se remarcă faptul că aproximativ $70 \%$ 
dintre răspunsuri au venit de la organizații private, $20 \%$ de la cele publice, și $10 \%$ de la cele nonprofit sau mixte. Acest fapt relevă nu doar interesul mai mare al sectorului privat pentru astfel de studii, ci și faptul că există consens, dacă afirmăm că tendințele specifice MRU din zilele noastre își au originile în practicile și politicile organizațiilor civile. În lumina considerațiilor științifice privind conceptualizarea MRU, pentru analiza datelor din raportul Cranet, vom avea în vedere următoarele subiecte: procesul de recrutare și selecție, formarea și dezvoltarea resurselor umane și evaluarea din perspectiva orientării spre performanță.

În ceea ce privește procesele de recrutare și selecție, rezultatele par a fi convergente.

În primul rând, cea mai mare parte dintre companii preferă să-și recruteze managerii din surse interne, un rol important avându-l site-urile web proprii. Celelalte metode populare sunt siteurile comerciale de locuri de muncă și agențiile de recrutare, în timp ce rețelele de socializare sunt tot mai populare în țările membre ale UE, dintre care se remarcă Marea Britanie, Belgia și Țările de Jos. Imaginea se diversifică ușor, în cazul recrutării celorlate categorii de profesioniști, pentru care organizațiile preferă, pe lângă metodele mai sus menționate, recomandările verbale și mass-media socială, utilizată de peste $20 \%$ dintre organizațiile participante. În al doilea rând, cele mai utilizate metode de selecție a managerilor și profesioniștilor sunt referințele și interviurile, testele de abilități, psihometrice, tehnice, de calcul etc., și procesul desfăşurat online fiind mai puțin folosit. În plus, social media este utilizată în procesul de selecție în toate țările, dar pare să fie mai răspândită în țările din Europa de Nord, în Belgia, Franța, Țările de Jos și Suedia. Pentru celelalte categorii de angajați, metode de selecție, precum recomandările, interviurile, formularele de cerere și testele sunt utilizate pe scară largă.

Referitor la acest subiect, răspunsurile organizațiilor din România arată că metodele de recrutare a managerilor sunt similare cu cele ale companiilor din Europa. Pentru recrutarea profesioniștilor și a celorlalte categorii de personal, cele mai utilizate metode sunt recomandările verbale, site-urile companiilor şi agenţiile de joburi. Anunțurile în ziare rămân o metodă încă utilizată pentru recrutarea categoriilor de personal, altele decât managerii și profesioniștii. În procesul de selecție a tuturor categoriilor de personal, organizațiile din România se remarcă prin faptul că cea mai utilizată metodă este reprezentată de formularele de aplicare pentru joburi, adiacent folosindu-serecomandările verbale, interviurileunu la unu/panel și testele de abilităţi/psihometrice.

Al doilea subiect este importanța formării şi dezvoltării resurselor umane în asigurarea competențelor necesare angajaţilor pentru atingerea obiectivelor organizaționale și crearea unui avantaj competitiv. Astfel, acordarea unui rol strategic pentru procesul de formare și dezvoltare a resurselor umane constituie o tendință cheie în MRU de astăzi. În medie, majoritatea țărilor din UE, din afara UE și din afara Europei $(62,2 \% ; 66 \%$ și, respectiv, 68\%) au o strategie scrisă în domeniul formării și dezvoltării resurselor umane. De asemenea, un procent foarte mic de companii din toate țările, cuprins între 3 și $6 \%$, externalizează complet procesul de formare și dezvoltare, majoritatea utilizând într-o măsură semnificativă furnizorii interni în astfel de programe. În plus, investitiiile în formarea și dezvoltarea resurselor umane au însumat în medie 3,21\% din bugetul anual de salarizare în țările membre ale UE, 3,34\% în țările non-UE și 4,47 în cele noneuropene.

La nivelul organizațiilor din țara noastră, remarcăm o rată de investițieîn formare și dezvoltare mai mare decât media țărilor membre ale UE cu aproximativ $1,29 \%$ și o clasare în topul statelor care au cheltuit cel mai mult pentru instruire.

În general, pentru determinarea nevoilor de formare și dezvoltare a resurselor umane, organizațiile se bazează într-o mare măsură pe datele obținute în urma procesului de evaluare. În medie, 74\% dintre companiile din țările UE își folosesc sistemele de evaluare pentru a determina nevoile de formare și dezvoltare. Cu toate acestea, există diferențe semnificative între țările membre. Spre exemplu, în timp ce Franța, Țările de Jos, Spania și Marea Britanie se bazează pe această abordare $(89 \%, 85 \%, 87 \%, 86 \%)$, la polul opus se află Suedia, Ungaria, Finlanda, România, Slovacia, Slovenia și Cipru $(45 \%, 48 \%, 60 \%, 62 \%, 63 \%, 62 \%$, $61 \%)$.

Privitor la tehnicile utilizate pentru a aprecia eficacitatea proceselor de formare și dezvoltare, în procent de aproximativ $70,2 \%$, organizațiile din țările membre ale UE folosesc cu predilecție evaluarea la sfârșitul programelor. Alte metode de 
evaluare preferate sunt: feedbackul informal de la managerii de linie, feedbackul informal din partea angajaților și gradul de îndeplinire a obiectivelor $(66,6 \%, 64,7 \%, 66,9 \%)$. Metodele de evaluare folosite foarte puțin sunt: performanţa la job înainte şi imediat după încheierea perioadei de instruire, respectiv la câteva luni după finalizarea acesteia, numărul zilelor de instruire și rentabilitatea investiţiei $(20,9 \%, 29,2 \%, 48,7 \%$ și $14 \%)$. Spre deosebire de acestea, în organizațiile din țările non-UE feedbackul informal de la managerii de linie $(60 \%)$ este cea mai comună tehnică.

Comparativ cu celelalte state din UE, în România, organizațiile raportează că preferă să folosească următoarele tehnici: zile de instruire efectuate, evaluarea imediat după finalizarea instruirii, gradul de îndeplinire a obiectivelor și feedbackul informal de la managerii de linie $(65,8 \%, 50 \%, 48,3 \%, 37,8 \%)$.

În ultimă instanță, răspunsurile organizațiilor din țările membre ale UE arată că, privitor la metodele de dezvoltare a carierei angajaților, cele mai multe dintre acestea folosesc următoarele metode: formarea la locul de muncă, proiectele de lucru în echipă, coachingul, mentoratul, taskurile speciale $(90 \%, 84,5 \%, 73,4 \%, 71 \%, 72,9 \%)$, un accent mai scăzut fiind pus pe instruirea în centrele de dezvoltare $(35,9 \%)$.

Comparativ, majoritatea organizațiilor din România raportează că cele mai utilizate metode în dezvoltarea carierei angajaţilor sunt: formarea la locul de muncă, coachingul, mentoratul, proiectele bazate pe lucrul în echipă și proiectele care stimulează învățarea $(97,8 \%, 95,6 \%, 76 \%, 73,8 \%$, $82,2 \%, 79,1 \%$ ).

Referitor la evaluarea resurselor umane, aceasta are în vedere importanța dată de companii unor aspecte, precum: acordarea recompenselor/ remunerațiilor/altor beneficii pecuniare, în funcție de performanță și utilizarea metodele de comunicare directă cu angajații.

Comparativ cu nivelurile raportate de ancheta Cranet din perioada 2008-2010, în studiul publicat în 2017 observăm că acordarea salariilor, în funcție de performanță, este, în general, mai utilizată în majoritatea țărilor. Astfel, remarcăm că variabilitatea salariului, în funcție de ratingurile de performanță individuale sau colective, este mult mai frecvent utilizată $(64 \%, 61 \%)$, comparativ cu posibilitatea de a participa financiar prin intermediul obținerii unui procent din profit (30\%), existând o creștere semnificativă a acestei tendințe, față de perioada 2008-2010. Totodată, sondajul arată că această modalitate se practică în special pentru personalul cheie și mai puțin pentru celelalte categorii de personal.

Privitor la modalităţile prin care beneficiile pecuniare sunt legate de performanţă, observăm o similitudine între grupurile țintă ale sondajului și o abordare diferită în ceea ce privește organizațiile din România. Această discrepanță privind modalităţile preferate de organizațiile din România se bazează cel mai probabil pe diferențele culturale legate de reticența în acceptarea acestor forme de salarizare variabilă, precum și pe reglementările normative, sugerând că există o abordare mai puțin orientată spre remunerarea bazată pe performanță.

Comparativ cu rata medie a organizațiilor din țările membre ale UE care comunică informațiile legate de strategia de afaceri, performanţa la job și organizarea muncii profesioniştilor și a celorlalte categorii de personal $(51,3 \%)$, doar $25 \%$ dintre companiile din România au o astfel de abordare. De regulă, în majoritatea organizaţiilor din grupurile țintă de țări, angajații își comunică opiniile supraveghetorului nemijlocit. Alte metode de comunicare „de jos în sus" sunt întâlnirile şi informarea prin intermediul mijloacelor electronice.

$\mathrm{Cu}$ toate că, în general, companiile din România converg spre tendințele specifice țărilor membre ale UE, remarcăm faptul că există unele aspecte distincte legate cel mai probabil de tipologia culturală, de cadrul instituțional moștenit din perioada anterioară anilor ' 89 , de gradul de tehnologizare, de infrastructură sau de unii determinanți normativi, care își pun amprenta asupra modului de funcționare a organizațiilor de astăzi - în contextul unui mediu economic de tranziţie spre Occident, care se presupune a fi încheiat și continuat cu un proces de modelare a societății perpetuu'.

Pe de o parte, convergența poate fi atribuită în mare măsură numărului crescut de companii multinaționale, provenite, de obicei, din țările dominante din punct de vedere economic la nivelul UE și nu numai, care infuzează mecanisme și practici de MRU specifice. Pe de altă parte, analizând datele anchetei Cranet, observăm că, în raport cu organizațiile din Occident, există o 
anumită rigiditate vizavi de orientarea către o abordare informală a practicilor de MRU. Astfel, în organizațiile din România, există strategii generale de personal, dar frecvența celor specifice de recrutare, instruire sau formare este vizibil redusă.

Un alt aspect important este responsabilitatea descentralizată privind resursele umane. Practic, în organizatiile din România, colaborarea departamentului de MRU cu managerii de linie are caracter subsecvent, structura de personal purtând responsabilitatea deciziilor legate de angajați, iar comunicarea este încă marcată de autoritatea ierarhică formală. În ceea ce privește procesele de recrutare și selecție, chiar dacă organizațiile încă mai folosesc metodele tradiționale, cum ar fi formularele de aplicare pentru joburi, s-a evidențiat o tendință a acestora spre utilizarea celor bazate pe tehnologie, precum rețele social media.

Din punctul de vedere al evaluării, se observă lipsa corelației dintre rezultatele evaluării profesionale și stabilirea nevoilor de instruire, dar și o deschidere a organizațiilor spre utilizarea unor metode foarte populare de formare, cum ar fi mentoratul și coachingul. În definitiv, suntem în consens cu cele prezentate pe parcursul acestei secțiuni, dacă afirmăm faptul că practicile de MRU raportate ca fiind utilizate în organizațiile din România au perspective bune de orientare către optimizarea performanței la nivel organizațional.

Așadar, din perspectiva contemporană a MRU, contextualizarea rămâne deosebit de importantă, când se are în vedere cercetarea unor problematici din sfera gestionării resurselor umane, deoarece schimbările continue la scară largă în climatul economic, tehnologic, social, politic și juridic implică transformări în relația dintre principalii actori. Prin urmare, realizarea unui demers științific privind o problematică din sfera gestionării resurselor umane din organizațiile militare presupune identificarea specificului atât din perspectiva tendințelor și caracteristicilor menționate anterior, cât și din cea generată de caracterul specific al misiunilor forțelor armate.

\section{MRU în sistemul național de apărare \\ Particularități și orientări derivate} din MRU specific organizațiilor din România

$\mathrm{Cu}$ toate că raportul dintre organizațiile civile și cele militare s-a consacrat prin caracterul divergent dat de natura misiunilor strategice din societate, faptul că schimbările au avut un impact inerent și asupra scenariilor de conflict, acestea au marcat inclusiv conotațiile interne ale forțelor armate. În consecință, asemeni omologilor civili, organizațiile militare au trebuit să-și revizuiască abordarea strategică pentru a se adapta la mediul de securitate incert, consolidându-și statutul și eficiența la nivel naţional și nu numai.

Analizând din punctul de vedere al evoluţiei MRU în armata României, observăm că aceasta a urmat o traiectorie progresivă, asemănătoare procesului internațional parcurs de la etapa administrării, promovată de școala clasică, la cea specifică managementului personalului, continuat cu etapa antreprenorială și postantreprenorială, care marchează și maturizarea conceptului în anii '90, urmată de abordarea strategică ${ }^{10}$.

Într-o perspectivă largă, putem spune că, în secolul XXI, specificul MRU din organizațiile militare continuă să își aibă originile în misiunea generală a forțelor armate privind gestionarea legitimă a apărării naționale și colective. În pofida acestui aspect, se remarcă atenuarea acestui caracter, pe fondul sporirii capacității forțelor armate de a tolera o tipologie mai flexibilă din punctul de vedere al organizației și al proceselor asociate MRU -, ca o consecință a tehnologizării și sporirii transparenței, astfel încât să răspundă oportun provocărilor mediului de securitate internaţional.

Adiţional, este important să reținem că această evoluție presupune particularități inerente pentru sistemele de apărare ale fiecărui stat în parte, care, pentru a reprezenta complexitatea fenomenului și pentru a emite considerații analitice riguroase care să le explice, pot fi analizate prin prisma conceptelor și a prevederilor ce modelează aspecte importante ale MRU.

În virtutea acestui aspect, armata română din zilele noastre este produsul transformării succesive a sistemului de apărare începând cu anii ' 90 , ca o conditiie sine qua non a nevoii de a se adapta la imperativele privind dezvoltarea mediului internaţional și de a se integra în arhitectura de securitate euroatlantică, prin elaborarea unor noi strategii, doctrine etc., prin modernizarea structurilor de forțe, prin atenția acordată utilizării fondurilor financiare, prin perfecționarea pregătirii ș.a.m.d. În mod inerent, toate aceste modificări și-au pus amprenta asupra MRU. 
De altfel, particularitățile MRU din sistemul de apărare vor fi stabilite în conformitate cu prevederile normative specifice la nivel național, iar posibilele orientări vor fi enunțate prin prisma specificului general, identificat în subcapitolul anterior, și a liniilor de ghidaj, trasate la nivelul NATO.

În primul rând, procesele de recrutare și de selecție se desfășoară pe principiile congruenței dintre persoană și organizație (abreviat P-O), respectiv a potrivirii dintre abilitățile/atributele unei persoane și cerințele unui loc de muncă (abreviat P-J $)^{11}$, care urmăresc să rețină, dintr-un număr mare de candidați, doar pe cei care dovedesc potențial de a parcurge următoarea fază din punctul de vedere al intelectului, al angajamentului de rol, al caracterului și al capacității de aderare la valorile specifice unui grup de referință atât de special prin sarcinile atribuite. În acest sens, recrutarea are în vedere deținerea unei diplome care să ateste pregătirea educațională secundară. $\mathrm{O}$ cercetare $^{12}$, realizată de grupul de cercetare coordonat de Giuseppe Caforio, asupra ofițerilor europeni din 10 țări (Republica Cehă, Danemarca, Franța, Grecia, Italia, Lituania, Țările de Jos, Polonia, Suedia și Elveția) indică manifestarea câtorva tendințe majore privind recrutarea. Prima dintre acestea face referire la declinul recrutării ofițerilor strict din surse interne, fenomen care presupune o mai mare convergență cu organizaţiile civile. Similar acestui fenomen, sistemul național de apărare se bazează pe recrutarea din surse interne, chiar dacă atragerea candidaților din mediul civil are din ce în ce mai mult succes, mai ales în cadrul domeniilor de studii administrativ-tehnice.

În procesul de selecție, se utilizează ca metode: controlul medical, examinarea nivelului de pregătire fizică, teste de aptitudini și abilităţi (psihometrice, tehnice etc.), de personalitate și, frecvent, un interviu. De regulă, testele menționate produc scoruri, în funcție de care se stabilește ierarhia celor care ocupă unul dintre locurile scoase la concurs. Succint, selecția personalului militar se bazează pe examinarea a două dimensiuni: realizările educaționale din trecut față de potenţialul viitor, și luarea în considerare a stării medicale, fizice și psihice și a anumitor cunoștințe de bază, necesare viitorului rol, manifestate în momentele evaluării din ,,prezent”.

Deoarece un aspect cheie al acestei secțiuni este natura schimbătoare a MRU din domeniul militar, observăm că procesele de recrutare și de selecție a personalului, deși păstrează elemente convenţionale, precum sursele interne de încorporare în instituţiile sale, armata se poate orienta pe integrarea unor instrumente specifice organizațiilor civile. Spre exemplu, utilizarea tehnologiilor pentru promovarea ofertei și recrutare prin intermediul rețelelor sociale, așa încât armata să rămână competitivă în atragerea candidaților cu o bună pregătire educaţională.

În al doilea rând, dacă analizăm sumar direcțiile de acțiune menționate în strategia de securitate ${ }^{13}$, pentru domeniul de apărare, observăm că asigurarea unei resurse de înaltă calitate este legată de adaptarea arhitecturală a structurii de forțe în mod etapizat și de adaptarea procesului de instruire la provocările mediului de securitate prezent și anticipat.

În general, o posibilă descriere sintetică a specificului procesului de formare în domeniul militar poate fi concentrarea acestuia pe structurarea conceptelor doctrinare, având în vedere stabilirea unui raport optim între abordarea convențională și cea profesională - bazat pe „mobilizarea resurselor ca gestiune a talentelor și competențelor" ${ }^{\prime 14}$. Cu alte cuvinte, procesul de formare este asimilat instruirii, „desfășurată de armată pentru realizarea capacității personalului/forțelor de a îndeplini atribuțiile/ misiunile specifice, folosind echipamentul din dotare" ${ }^{15}$. Potrivit referinţelor specifice NATO, aceasta include dezvoltarea cunoștințelor, abilităţilor, aptitudinilor şi atributelor critice, care sunt necesare îndeplinirii sarcinilor de bază comune, a celor cu cerințe fizice ridicate și a celor asociate specialitătii militare.

În ceea ce privește orientările, concepția NATO privind schimbarea forțelor armate prin intermediul dimensiunilor de transformare a procesului de instruire vizează instrucția individuală, care capătă, în completarea dimensiunii instituţionale, tot mai multe valenţe legate de autodezvoltare. Acest aspect este susţinut şi de utilizarea tehnologiilor, care extind și îmbunătățesc metodele de învăţare convenționale. Una dintre cele mai importante tendințe este furnizarea de învățământ la distanţă, care, folosind instrumente informatizate, cu interacțiune sincronă, asincronă și mixtă, se raliază intenţiei NATO de a oferi instruire ,centrată pe cursant" atunci când și unde este necesar, crescând și susținând pregătirea în toată forța, armata regulată și componenta de rezervă ${ }^{16}$. În acest sens, formarea 
electronică se dezvoltă progresiv în organizațiile militare de la noi din țară, fiind susținută de platforme digitale, dar rămâne de analizat modul în care utilizarea instrumentelor informatizate influenţează atingerea obiectivelor de instruire, și acțiunile necesare a fi întreprinse în vederea gestionării performanței la nivel organizațional.

În ceea ce privește evaluarea, considerăm că, similar mediului civil, rezultatele depind de formularea obiectivelor din perspectiva analizei nevoilor de competențe viitoare, de abordarea metodologică și de instrumentele utilizate pentru desfășurarea procesului propriu-zis de formare, în consens cu scopurile. Procesul de evaluare din sistemul național de apărare se caracterizează prin evidențierea obiectivelor, a așteptărilor, a normelor și a valorilor prin traducerea acestora în criterii măsurabile, respectiv prin luarea deciziilor în ceea ce privește progresele individuale, recompensele, sancțiunile, ierarhizarea și selecționarea. Teoretic, această abordare ar trebui să se orienteze pe sporirea atenției acordate de militarii evaluați obiectivelor pe care le au de îndeplinit și pe responsabilizarea evaluatorilor, cărora le revine misiunea fundamentală de a asocia standardele de performanță cu sarcinile subordonaților și cu rezultatele așteptate. În esență, trecerea de la evaluarea care se realizează anual, pe baza unor standarde de performanță, la cea continuă constituie o posibilă orientare de viitor, cu multiple beneficii în ceea ce privește performanța organizațională.

Așadar, abordarea convențională continuă să rămână atributul fundamental atunci când analizăm specificul MRU în organizațiile militare. $\mathrm{Cu}$ toate că, în această secțiune, am remarcat limitele convergenței cu organizațiile civile - ca o consecință a determinismului culturii și misiunilor armatei, a rolului actorilor implicaţi, a dinamicii mediului de securitate și a cadrului normativ în examinarea variațiilor privind abordarea proceselor, asociate cu gestionarea personalului militar -, este evident că există și similarități cheie, legate de orientări prezente și viitoare, care apar atunci când ne referim la tehnologie și performanță.

\section{Concluzii}

Procesele asociate cu MRU în organizațiile din România prezintă în mare parte un caracter convergent $\mathrm{cu}$ caracteristicile specifice celor din țările membre ale UE, caracteristicile distincte ținând de decalajul pe linie de recunoaștere a orientărilor specifice, de revizuire în concordanță cu acestea și de transformare, pe măsură ce apar noi concepte și tehnologii.

În ceea ce privește gestionarea resurselor umane în organizațiile militare, armata recunoaște că oamenii reprezintă cel mai valoros atu, iar ajustarea proceselor specifice, de preferat imediat ce este sesizat cel mai mic impact al transformărilor externe asupra îndeplinirii misiunilor, este esenţială pentru îndeplinirea misiunilor. În general, este important să reținem că o astfel de abordare presupune particularități inerente pentru sistemul național de apărare, dar comportă o serie de caracteristici și orientări similare celor din celelalte tipuri de organizații, în contextul integrării instrumentelor care să faciliteze accesibilitatea la informații, angajabilitatea, dezvoltarea personală și performanța. În lumina acestui aspect, este puţin probabil să ne așteaptăm ca toate practicile convenționale din spectrul MRU să funcționeze, cheia fiind orientarea spre armonizarea acestora cu noi abordări și instrumente, care să fie consolidate instituțional, astfel încât armata să rămână o opțiune viabilă în competiția pentru atragerea și reținerea unei resurse umane de înaltă calitate și pentru construirea unui sistem de apărare capabil să răspundă oportun provocărilor din mediul de securitate actual.

Sintetizând, lucrarea prezintă următoarele contribuții personale:

- abordarea domeniului metodelor de analiză a caracteristicilor MRU la nivelul organizațiilor din România, comparativ cu organizații din alte țări (cu preponderență membre ale UE) - demers care are un caracter complementar cu lucrările anterioare, gândite din perspectiva explorării teoriei, observațiilor realizate la nivel macro ale practicii, examinării modelelor naționale, a sistemelor (public, privat, militar) etc.;

- aducerea în discuție a specificului MRU din organizațiile militare naționale în viziunea „convergență versus divergentă”, punctând particularitățile și orientările de actualitate.

Lucrarea prezintă limite ale cercetării, determinate de următoarele aspecte: analiza comparativă a datelor a inclus generalizări statistice (la nivelul anului 2015), care au surprins doar caracteristici și tendințe generale, definite prin combinarea datelor obținute de la mai mulți 
indivizi din cadrul organizațiilor, dar care nu sunt raportate la anumite standarde de referință, ceea ce le-ar putea considera mai puțin adecvate de către cei interesați de această problematică; mare parte din cadrul normativ specific gestionării personalului din sistemul naţional de apărare nu este pus la dispoziția publicului larg, ceea ce nu a permis creionarea unei imagini cu un grad de acuratețe ridicat privind particularitățile și orientările identificate.

În cele din urmă, principalele probleme deschise sunt: aprofundarea cadrului științific general abordat în lucrare; extinderea cercetărilor în domeniul de analiză a caracteristicilor MRU la nivelul organizațiilor militare din alte state, astfel încât să poată fi extrapolate ideile aplicabile în contexte relevante pentru a înţelege „,bunele practici"; dezvoltarea unor studii ample care să reflecte cum sunt procesele asociate MRU și de ce, prin adaptarea adecvată a metodelor de cercetare.

\section{NOTE:}

1 Frederik Winslow Taylor, The principles of Scientific Management, New York, 1911, http://www.drluisortiz. com / doc/articlefrontpage.pdf, accesat la 06.06.2021.

2 Dominique Roux, Analyse économique et gestion de l'entreprise, vol. 2, Editura Dunod, Paris, 1988, p. 236.

3 Jacoby Sanford, Business and Society in Japan and the United States, Institute for Technology, Enterprise and Competitiveness, 2005, pp. 5-14.

4 Donald P. Rogers, "Human resource management", The Encyclopedia of Human Resource Management - Short Entries, Editor Pfeiffer, San Francisco, 2012, vol. 1, p. 277.

5 Garry C. McMahan, Myrtle P. Bell, Meghna Virick, "Strategic human resource management: Employee involvement, diversity, and international issues", Human Resource Management Review, vol. 8(3), 1998, pp. 193-214.

6 Michael Armstrong, Armstrong's handbook of human resource management practice, Editura Kogan Page, London, 2014, p. 4.

7 Adriana Bădescu, Codruța Mirci, Gabriela Bogre, Managementul resurselor umane-manualul profesionistului, realizat în cadrul proiectului Phare 2005/ 017553.04.02.02.01.529 Intărirea rolului funcţiei de resurse umane în organizaţii, Timișoara, 2008, p. 12, http:// www.islavici.ro/cursuriold/Managementul_Resurselor Umane\%20-\%20, accesat la 15.09.2021.

$8 \mathrm{https}: / /$ businessapps.cranfield.ac.uk/cranet/, accesat la 04.08.2021.

9 Michael J. Morley, Noreen Heraty, "The anatomy of an international research collaboration: building cumulative comparative knowledge in human resource management", International Studies of Management \& Organization, vol. 49 (1), 2019, pp. 341-354.

10 Gheorghiță Căprărescu, Daniela G. Stancu, Georgiana Anghel, Managementul resursei umane, Editura Universitară, București, 2009, pp. 19-22.
11 TomokiSekiguchi,"Person-organizationfitandpersonjob fit in employee selection: a review of the literature", Osaka Keidai Ronshu, vol. 54 (6), 2004, pp. 179-191, https://www.irepository.net/i1/user_contents/02/ G0000031Repository/ repository/keidaironshu_054_006_179-196.pdf, accesat la 20.10.2021.

12 Rene Moelker, Joseph Soeters, Democratization of recruitment, apud G. Caforio, The European cadet: Professional socialisation in military academies, BadenBaden: Nomos, 1998, p. 91.

13 *** Strategia Națională de apărare a țării pentru perioada 2020-2024. Impreună, pentru o Românie sigură și prosperă într-o lume marcată de noi provocări, aprobată prin Hotărârea nr. 22 a ședinței comune a Senatului și Camerei Deputaților, din 30 iunie 2020, Monitorul Oficial, Partea I, nr. 574, din 01.07.2020, București, p. 42.

14 Emil Păun, Școala - abordare sociopedagogică, Editura Polirom, Iași, 1999, p. 143.

15 *** Doctrina instruirii Armatei României, București, 2006, p. 14.

$16 * * *$ Army regulation 350-1, Army Training and Leader Development,2017,p. 140, https://www.army resilience.army. mil/ard/images/pdf/Policy/AR\%20350-1\%20Army\%20 Training\%20and\%20Leader\%20Development \%20\%20.pdf, accesat la 28.08.2021.

\section{BIBLIOGRAFIE}

*** Army regulation 350-1, Army Training and Leader Development, 2017, https://www. armyresilience.army.mil/ard/images/pdf/Policy/ AR\%20350-1\%20Army\%20Training \%20and $\% 20$ Leader\%20Development \%20\%20.pdf

***Doctrina instruirii Armatei României, București, 2006.

*** Strategia Națională de apărare a țării pentru perioada 2020-2024. Impreună, pentru o Românie sigură și prosperă într-o lume marcată de noi provocări, aprobată prin Hotărârea nr. 22 a ședinței comune a Senatului și Camerei Deputaților, din 30 iunie 2020, Monitorul Oficial, Partea I, nr. 574, din 01.07.2020, București.

Armstrong Michael, Armstrong's handbook of human resource management practice, Editura Kogan Page, Londra, 2014.

Bădescu Adriana, Mirci Codruța, Bogre Gabriela, Managementul resurselor umane manualul profesionistului, realizat în cadrul proiectului Phare 2005/ 017-553.04.02.02.01.529 Intărirea rolului funcţiei de resurse umane în organizații, Timişoara, 2008, http://www.islav ici.ro/cursuriold/Managementul_Resurselor_ Umane $\% 20-\% 20$ 
Caforio G., The European cadet: Professional socialisation in military academies, Baden-Baden: Nomos, 1998.

Căprărescu Gheorghiță, Stancu G. Daniela, Anghel Georgiana, Managementul resursei umane, Editura Universitară, București, 2009.

Emil Păun,Școala-abordaresociopedagogică, Editura Polirom, Iași, 1999.

Jacoby Sanford, Business and Society in Japan and the United States, Institute for Technology, Enterprise and Competitiveness, 2005.

McMahan Garry, Bell P. Myrtle, Meghna Virick, "Strategic human resource management: Employee involvement, diversity, and international issues", Human Resource Management Review, vol. 8(3), 1998.

Morley Michael, Heraty Noreen, "The anatomy of an international research collaboration: building cumulative comparative knowledge in human resource management", International Studies of Management \& Organization, vol. 49 (1), 2019.
Rogers P. Donald, "Human resource management", The Encyclopedia of Human Resource Management - Short Entries, vol. 1, Editor Pfeiffer, San Francisco, 2012.

Roux Dominique, Analyse économique et gestion de l'entreprise, vol. 2, Editura Dunod, Paris, 1988.

Sekiguchi Tomoki, "Person-organization fit and person-job fit in employee selection: a review of the literature", Osaka Keidai Ronshu, vol. 54 (6), 2004, https://www.i-repository.net/il/user contents/02/G0000031Repository/repository/ keidaironshu_054_006_179-196.pdf

Taylor Frederik Winslow, The principles of Scientific Management, New York, 1911, http:// www.drluisortiz. com/doc/articlefrontpage.pdf

https://businessapps.cranfield.ac.uk/cranet/ http://www.drluisortiz. com /doc/articlefro ntpage.pdf 